\title{
Faktor-Faktor Yang Mempengaruhi Profitabilitas Perusahaan Otomotif Di Bursa Efek Indonesia
}

\section{Gusti Ayu Agung Mirah Sanjiwani ${ }^{1}$ Ketut Alit Suardana ${ }^{2}$}

\author{
${ }^{1,2}$ Fakultas Ekonomi dan Bisnis Universitas Udayana (Unud), Bali, Indonesia \\ e-mail: mirahsanjiwani.1993@gmail.com
}

\begin{abstract}
ABSTRAK
Penelitian ini bertujuan untuk menguji secara empiris pengaruh perputaran kas, perputaran piutang, perputaran persediaan dan perputaran modal terhadap perolehan profitabilitas di perusahaan otomotif yang terdaftar di Bursa Efek Indonesia periode 2012-2016. Data yang dipergunakan dalam penelitian ini adalah data sekunder yang diperoleh dari wesite www.idx.co.id. Teknik analisis yang digunakan dalam penelitian ini adalah analisis linear berganda. Hasil analisis menujukan perputaran kas berpengaruh signifikan terhadap profitabilitas. Hal ini menunjukkan bahwa meningkatnya perputaran kas perusahaan otomotif, maka cenderung akan meningkatkan profitabilitas. Perputaran piutang berpengaruh signifikan terhadap profitabilitas. Hal ini menunjukkan bahwa meningkatnya perputaran piutang perusahaan otomotif, maka cenderung akan meningkatkan profitabilitas. Perputaran persediaan berpengaruh signifikan terhadap profitabilitas. Hal ini menunjukkan bahwa meningkatnya perputaran persediaan perusahaan otomotif, maka cenderung akan meningkatkan profitabilitas. Perputaran modal kerja berpengaruh signifikan terhadap profitabilitas. Hal ini menunjukkan bahwa meningkatnya perputaran modal kerja perusahaan otomotif, maka cenderung akan meningkatkan profitabilitas.
\end{abstract}

Kata Kunci: Perputaran kas, perputaran piutang, perputaran persediaan, perputaran modal kerja, profitabilitas

\begin{abstract}
This study aims to empirically examine the effect of cash turnover, accounts receivable turnover, inventory turnover and capital turnover on profitability in automotive companies listed on the Indonesia Stock Exchange for the period 2012-2016. The data used secondary data obtained from the website www.idx.co.id. The analysis technique used is multiple linear analysis. The results show that cash turnover have significant effect on profitability. This shows that the increase in cash turnover of automotive companies tends to increase profitability. Account receivable turnover has significant effect on profitability. This shows that the increase in automotive company accounts receivable turnover tends to increase profitability. Inventory turnover has significant effect on profitability. This shows that the increasing inventory turnover of automotive companies tends to increase profitability. Working capital turnover has significant effect on profitability. This shows that the increase in turnover of working capital of automotive companies tends to increase profitability.

Keywords: cash turnover, accounts receivable turnover, inventory turnover, working capital turnover, operating profit
\end{abstract}


I Gusti Ayu Agung Mirah Sanjiwani dan Ketut Alit Suardana. Faktor ...

\section{PENDAHULUAN}

Seiring dengan pertumbuhan ekonomi, dunia bisnis kian berkembang. Jumlah perusahaan terus bertambah tiap tahunnya. Perusahaan adalah suatu organisasi yang mengolah input berupa faktor produksi menjadi output berupa barang dan jasa bagi konsumen. Berdasarkan berita resmi Badan Pusat Statistik (BPS), hasil final pendaftaran (listing) perusahaan/usaha Sensus Ekonomi menunjukkan bahwa jumlah seluruh perusahaan/usaha di luar sektor pertanian tercatat sebanyak 22,7 juta. Dibandingkan tahun 1996, jumlah perusahaan/usaha meningkat 6,3 juta, atau 3,32 persen per tahun. Menurut lapangan usaha yang banyak bermunculan dan tumbuh semakin cepat, hal ini merupakan suatu dampak yaitu yang ditandai dengan semakin meningkatnya suatu persaingan usaha yang kompetitif. Menghadapi persaingan tersebut, perusahaan dituntut untuk mampu menciptakan atau meningkatkan nilai perusahaan agar tujuan perusahaan tersebut tercapai.

Pada umumnya perusahaan didirikan bertujuan untuk memperoleh suatu laba yang optimum, karena laba merupakan penunjang kelangsungan hidup perusahaan. Selain itu, laba merupakan salah satu ukuran kemampuan perusahaan dalam melakukan kegiatan operasional usahanya. Untuk mencapai tujuan tersebut maka diperlukan modal kerja perusahaan yang efektif dan efisien. Besarnya modal kerja harus sesuai dengan kebutuhan perusahaan, karena modal kerja yang berlebihan atau kekurangan modal kerja sama-sama membawa dampak negatif bagi perusahaan. 
Munawir (2015:80) untuk menilai keefektifan modal kerja dapat menggunakan rasio antara total penjualan dengan modal kerja dengan modal kerja rata-rata (working capital turn over). Rasio ini dapat menunjukkan hubungan antara modal kerja dengan penjualan, dan menunjukkan banyaknya penjualan yang dapat diperoleh perusahaan untuk tiap rupiah (Rp) modal kerja. Perputaran yang lama menunjukkan adanya kelebihan modal kerja yang disebabkan rendahnya perputaran persediaan, piutang atau adanya saldo kas yang terlalu besar.

Lamanya periode perputaran tergantung dari sifat atau kegiatan operasi suatu perusahaan, lama atau cepatnya perputaran ini juga akan menentukan besar atau kecilnya kebutuhan modal kerja. Perputaran modal kerja diharapkan terjadi dalam jangka waktu yang relatif pendek, sehingga modal kerja yang ditanamkan cepat kembali. Periode perputaran modal kerja mulai pada saat dimana kas yang tersedia diinvestasikan dalam komponen-komponen modal kerja sampai saat dimana kembali lagi pada kas. Komponen modal kerja tersebut adalah kas dan bank, piutang, dan persediaan (Machmud dkk., 2015). Semakin tinggi tingkat perputaran kas, piutang dan persediaan menunjukkan tingginya volume penjualan yang dicapai oleh perusahaan, dan laba yang diterima akan menjadi banyak jumlahnya. Profitabilitas yang diterima adalah selisih antara lama bruto dan beban usaha, profitabilitas yang diperoleh semata-mata dan kegiatan utama perusahaan.

Penelitian ini merupakan penelitian replikasi dari penelitian yang telah dilakukan oleh Sufiana dan Purnawati (2012). Hasil penelitian Sufiana dan Pumawati menyatakan variabel perputaran kas tidak berpengaruh signifikan 
terhadap profitabilitas. Teori yang dikemukakan oleh Rudianto (2009) di dalam neraca, kas merupakan aset yang paling lancar, dalam arti kas paling sering berubah-ubah, hal ini disebabkan oleh adanya transaksi yang terjadi dengan pihak luar perusahaan.

Penelitian yang dilakukan oleh Lestari (2017) menunjukkan bahwa secara simultan perputaran kas dan perputaran piutang berpengaruh secara signifikan terhadap profitabilitas pada perusahaan sub sektor makanan dan minuman yang terdaftar di Bursa Efek Indonesia tahun 2011 - 2015. Tiong (2017) juga melakukan penelitian tentang piutang yang hasilnya menunjukkan bahwa tingkat perputaran piutang berpengaruh signifikan terhadap profitabilitas. Hal ini yang bertentangan ditemukan dalam penelitian yang dilakukan oleh Dodokerang dkk. (2018) yang menyatakan bahwa perputaran piutang tidak berpengaruh signifikan terhadap profitabilitas.

Verawati dan Oetomo (2014) modal kerja adalah investasi sebuah perusahaan pada aktiva-aktiva jangka pendek-kas, surat-surat berharga, persediaan dan piutang. Kas adalah aset perusahaan yang paling likuid dan karena itu dicantumkan pada urutan aset yang pertama dalam kelompok asset lancar. Jadi rasio perputaran kas ini bermanfaat untuk mengukur tingkat kecukupan modal kerja perusahaan yang dibutuhkan membayar tagihan dan membiayai penjualan. Selain kas, faktor lainnya yang mempengaruhi jumlah modal kerja adalah piutang. Piutang merupakan bentuk penjualan yang dilakukan oleh suatu perusahaan dimana pembayarannya tidak dilakukan secara tunai, namun bersifat bertahap. 
Hubungan penjualan kredit dan piutang usaha dinyatakan sebagai perputaran piutang. Rasio ini dihitung dengan membandingkan antara penjualan kredit bersih dengan rata-rata piutang bersih (Kasmir, 2016:140).

Persediaan adalah sejumlah barang jadi, bahan baku, barang dalam proses yang dimiliki perusahaan dengan tujuan untuk dijual atau diproses lebih lanjut. Pengendalian persediaan yang efektif diperlukan untuk memelihara jumlah, jenis dan kualitas barang yang sesuai dan mengatur investasi dalam persediaan. Menurut Rahayu dkk (2017), perputaran persediaan adalah menunjukkan seberapa cepat perputaran persediaan dalam siklus produksi normal. Salah satu cara untuk mengetahui kinerja keuangan perusahaan adalah dengan melihat kemampuan perusahaan dalam memperoleh laba melalui rasio profitabilitas. Semakin baik rasio profitabilitas maka semakin bagus, karena menggambarkan tingginya perolehan keuntungan perusahaan. Rasio profitabilitas dalam hubungannya dengan investasi, menggunakan dua pengukuran yaitu return on investment dan return on assets. Dalam penelitian Saputra (2017) juga ditemukan hasil yang sama yaitu modal kerja berpengaruh secara signifikan terhadap profitabilitas perusahaan.

Perputaran kas merupakan perbandingan antara penjualan dengan jumlah kas rata-rata. Perputaran kas menunjukkan kemampuan kas dalam menghasilkan pendapatan sehingga dapat dilihat berapa kali uang kas berputar dalam satu periode tertentu. Semakin tinggi perputaran kas ini akan semakin baik. Karena ini berarti semakin tinggi efisiensi penggunaan kasnya dan keuntungan yang diperoleh akan semakin besar pula (Kasmir, 2016). Hal ini sejalan dengan 
penelitian Nuriyani (2017) dan Putri (2016) yang menyatakan perputaran kas berpengaruh terhadap profitabiltas.

Perputaran kas berfungsi untuk mengukur tingkat kecukupan modal kerja perusahaan yang dibutuhkan untuk membayar tagihan dan membiayai penjualan. Artinya untuk mengukur tingkat ketersediaan kas untuk membayar tagihan (utang) dan biaya-biaya yang berkaitan dengan penjualan. Hasil studi lain dari Haryanto et al. (2018) menyebutkan bahwa perputaran kas berpengaruh terhadap profitabiltas. Penelitian lain dari Kasozi (2017) juga menyatakan bahwa perputaran kas berpengaruh positif terhadap profitabiliats. Artinya naik turunnya persdiaan kas akan mempengaruhi profitabilitas usaha.

$\mathrm{H}_{1}$ : Perputaran kas berpengaruh positif dan signifikan terhadap profitabilitas

Piutang merupakan salah satu bentuk investasi yang menyerap sebagian dari modal perusahaan. Bila perusahaan menggunakan modal sendiri seluruhnya, maka dengan piutang modal yang tersedia untuk investasi bentuk lain (persediaan, aktiva tetap dan lain-lain) akan berkurang. Dengan demikian, biaya modal besarnya sama dengan besarnya biaya modal sendiri. Bilamana modal sendiri tidak mencukupi sehingga perusahaan terpaksa menggunakan pinjaman bank, maka timbul biaya yang eksplisit dalam bentuk bunga modal pinjaman.

Peningkatan piutang yang diiringi oleh meningkatnya piutang tak tertagih perlu mendapat perhatian. Untuk itu sebelum suatu perusahaan memutuskan melakukan penjualan kredit, maka terlebih dahulu diperhitungkan mengenai jumlah dana yang diinvestasikan dalam piutang, syarat penjualan dan pembayaran 
yang diinginkan, kemungkinan kerugian piutang (piutang tak tertagih) dan biayabiaya yang akan timbul dalam menangani piutang bisa diatasi. Hal ini didukung oleh penelitian Tiong (2018) dan Damanik (2011) serta penelitian Inastia (2018) bahwa perputaran piutang berpengaruh signifikan terhadap profitabilitas (ROA). Hasil studi empiris Lydia (2018) dan Jindal et al. (2017) yang menemukan bahwa perputaran piutang berpengaruh signifikan terhadap profitabilitas (ROA).

$\mathrm{H}_{2}$ : Perputaran piutang berpengaruh positif dan signifikan terhadap profitabilitas.

Setiap perusahaan, apakah perusahaan itu perusahaan perdagangan ataupun perusahaan pabrik serta perusahaan jasa selalu mengadakan persediaan. Tanpa adanya persediaan, para pengusaha akan dihadapkan pada resiko bahwa perusahaannya pada suatu waktu tidak dapat memenuhi keinginan pelanggan yang memerlukan atau meminta barang/jasa. Persediaan diadakan apabila keuntungan yang diharapkan dari persediaan tersebut hendaknya lebih besar daripada biayabiaya yang ditimbulkannya.

Periode perputaran persediaan ini perlu diperhatikan untuk mengetahui berapa lama waktu yang dibutuhkan oleh perusahaan untuk menghabiskan persediaan dalam proses produksinya. Hal ini dikarenakan semakin lama periode perputaran persediaan, maka semakin banyak biaya yang harus dikeluarkan oleh perusahaan untuk menjaga agar persediaan di gudang tetap baik. Oleh karena itu diperlukan penghematan ongkos penyimpanan dan pemeliharaan agar keuntungan yang diperoleh semakin besar sehingga semakin kecil biaya yang harus ditanggung perusahaan, semakin besar laba yang akan didapat dan perputaran persediaan semakin tinggi. Hal ini didukung oleh hasil penelitian dari Setiyanto 
(2018) dan Ariati (2011) serta Mwaura (2017) menyatakan bahwa perputaran persediaan memberikan pengaruh signifikan terhadap profitabilitas.

$\mathrm{H}_{3}$ : Perputaran persediaan berpengaruh positif dan signifikan terhadap profitabilitas.

Munawir (2015) menyatakan bahwa rasio perputaran modal kerja menunjukkan hubungan antara modal kerja dengan penjualan. Faktor modal kerja mempengaruhi tinggi rendahnya profitabilitas. Setiap perusahaan dalam operasionalnya membutuhkan modal karena modal berpengaruh terhadap perusahaan untuk mencapai tujuannya, sehingga profitabilitas tinggi sangat mendukung operasional perusahaan secara maksimal (Indradewi dan Widyarti, 2016).

Penelitian ini sebelumnya sudah dilakukan oleh Tran et al. (2017) yang mengemukakan bahwa efisiensi manajemen modal kerja berpengaruh signifikan terhadap profitabilitas. Penelitian tersebut diperkuat Sariyana (2016), Kusumo (2018) dan Felany (2018), Rasyid (2015) menunjukkan bahwa perputaran modal kerja (working capital turnover) berpengaruh positif terhadap profitabilitas.

$\mathrm{H}_{4}$ : Perputaran modal kerja berpengaruh positif dan signifikan terhadap profitabilitas.

\section{METODE PENELITIAN}

Penelitian ini menggunakan penelitian berbentuk kausalitas. Penelitian kausalitas merupakan penelitian yang dilakukan untuk mengetahui hubungan antara suatu variabel bebas terhadap variabel terikat. Jadi penelitian ini dilakukan untuk mengetahui pengaruh perputaran kas, perputaran piutang, perputaran persediaan, 
dan modal kerja terhadap profitabilitas pada perusahaan otomotif di Bursa Efek Indonesia periode 2012-2016. Penelitian ini dilakukan pada Bursa Efek Indonesia dengan cara mengakses laman www.idx.co.id dan ICMD (Indonesian Capital Market Directory) guna mendapatkan informasi yang diperlukan dalam penelitian ini.

Variabel terikat dalam penelitian ini adalah profitabilitas. Profitabilitas merupakan kemampuan perusahaan memperoleh laba dalam hubungan dengan penjualan, total aktiva maupun modal sendiri. Profitabilitas itu sendiri dipengaruhi oleh banyak faktor. Untuk mengetahui faktor-faktor profitabilitas dalam suatu perusahaan, dapat digunakan rasio keuangan.

Variabel bebas dalam penelitian ini adalah perputaran kas, perputaran piutang, perputaran persediaan, dan modal kerja. Tingkat perputaran kas merupakan periode berputarnya kas yang dimulai pada saat kas diinvestasikan dalam komponen modal kerja sampai saat kembali menjadi kas sebagai unsur modal kerja yang paling tinggi tingkat likuiditasnya. Rasio perputaran piutang mengukur berapa kali rata-rata piutang dapat tertagih selama satu periode . Pengelolaan piutang suatu perusahaan dapat dilihat dari tingkat perputaran piutangnya, dimana tingkat perputaran piutang merupakan periode terikatnya modal kerja dalam piutang (Erik dkk., 2014).

Perputaran persediaan adalah menunjukkan seberapa cepat perputaran persediaan dalam siklus produksi normal. Perputaran modal kerja atau working capital turn over merupakan salah satu rasio untuk mengukur atau menilai keefektifan modal kerja perusahaan selama periode tertentu. ... Untuk menilai 
keefektifan modal kerja dapat digunakan ratio antara total penjualan dengan jumlah modal kerja rata-rata.

Jenis data yang digunakan dalam penelitian ini adalah data kuantitatif dan kualitatif. Data kuantitatif dalam penelitian ini adalah laporan keuangan tahunan perusahaan otomotif yang terdaftar di Bursa Efek Indonesia periode 2012-2016. Data kualitatif dalam penelitian ini adalah daftar nama-nama perusahaan yang diteliti laporan keuangannya, laporan auditor independen, profil perusahaan, dan catatan atas laporan keuangan. Data dalam penelitian ini merupakan data sekunder eksternal berupa annual report dengan metode observasi non partisipan yaitu mencatat data yang diakses melalui situs BEI. Populasi penelitian ini diambil dari seluruh perusahaan

Populasi dalam penelitian ini adalah perusahaan otomotif yang terdaftar di BEI periode 2012-2016. Populasi ini dipilih karena perusahaan otomotif memiliki prospek yang cerah di masa mendatang. Hal ini terlihat dari banyaknya permintaan otomotif sehingga menyebabkan tingginya tingkat investasi di sektor ini. Metode pengambilan sampel dilakukan dengan pendekatan purposive sampling untuk menentukan sampel dari populasi yang memenuhi kriteria sesuai dengan yang penulis kehendaki, yaitu: 1) Perusahaan sektor atomotif yang menerbitkan dan mempublikasikan laporan tahunan auditan selama periode 20122016 dan 2) Ukuran transaksi yang digunakan rupiah.

Metode pengumpulan data menggunakan metode observasi non partisipan. Pengumpulan data dilakukan dengan dokumentasi dari sumber yang digunakan, 
yaitu laporan keuangan auditan perusahaan sampel. Data yang diperoleh merupakan data yang berasal dari berbagai sumber antara lain laman dari BEI (www.idx.co.id) dan ICMD (Indonesian Capital Market Directory).

Teknik analisis yang digunakan dalam penelitian ini adalah analisis regresi berganda, yang dilakukan untuk mengetahui hubungan antar lebih dari dua variabel, yaitu satu variabel sebagai variabel dependen dan beberapa variabel lain sebagai variabel independen. Pengujian hipotesis dengan analisis regresi linear berganda pada penelitian ini diformulasikan sebagai berikut:

$$
\hat{Y}=\alpha+\beta_{1} X_{1}+\beta_{2} X_{2}+\beta_{3} X_{3}+\beta_{3} X_{3}+\beta_{4} X_{4}+e
$$

Keterangan:

$$
\begin{array}{ll}
\hat{\mathrm{Y}} & =\text { profitabilitas } \\
\alpha & =\text { konstanta } \\
\beta & =\text { koefisien regresi parsial } \\
\mathrm{X}_{1} & =\text { perputaran kas } \\
\mathrm{X}_{2} & =\text { perputaran piutang } \\
\mathrm{X}_{3} & =\text { perputaran persediaan } \\
\mathrm{X}_{4} & =\text { perputaran modal kerja } \\
\mathrm{e} & =\text { standar error }
\end{array}
$$

\section{HASIL DAN PEMBAHASAN}

Sejarah Bursa Efek Indonesia yang didirikan oleh Pemerintah Belanda di Indonesia telah dimulai sejak tahun 1912 namun kemudian ditutup karena Perang Dunia I. Pada tahun 1977 bursa dibuka ke mbali dan dikembangkan menjadi bursa modal yang modern dengan menerapkan Jakarta Automoted Trading Systems (JATS) yang terintegrasi dengan sistem kliring dan penyelesaian, serta depositori saham yang dimiliki oleh PT. Kustodi dan Depositori Efek Indonesia (KDEI). Dengan mengenai Harga saham Gabungan (IHSG). 
I Gusti Ayu Agung Mirah Sanjiwani dan Ketut Alit Suardana. Faktor ...

Perdagangan surat berharga dimulai di Pasar Modal Indonesia sejak 3 Juni 1952. Namun tonggak paling besar terjadi pada 10 Agustus 1977, yang dikenal sebagai kebangkitan Pasar Modal Indonesia. Setelah Bursa Efek Jakarta dipisahkan dari Institusi Bapepam tahun 1992 dan diswastakan, mulailah pasar modal mengalami pertumbuhan yang Sangat pesat. Pasar modal tumbuh pesat periode 1992 - 1997. Krisis di Asia Tenggara tahun 1977 membuat pasar modal jatuh. Indeks Harga Saham Gabungan (IH SG) Turun ke posisi paling rendah. Bagaimanapun, masalah pasar modal tidak lepas dari arus investasi yang akan menentukan pertumbuhan ekonomi sebuah kawasan, tidak terkecuali Indonesia dan negara- negara di Asia Tenggara lainnya.

Analisis statistik deskriptif memberikan gambaran atau deskripsi suatu data yang dilihat dari besarnya nilai minimum, maksimum, mean, dan simpangan baku (standard deviation) dengan $\mathrm{N}$ merupakan banyaknya responden penelitian. Hasil analisis statistik deskriptif dapat dilihat dalam Tabel 1.

Tabel 1.

\section{Statistik Deskriptif}

\begin{tabular}{lrrrrr}
\hline & N & Minimum & Maximum & \multicolumn{1}{c}{ Mean } & Std. Deviation \\
\hline perputaran kas & 25 & 5,82 & 5,82 & 15,8956 & 7,37067 \\
perpuataran piutang & 25 & 2,10 & 26,21 & 7,7084 & 5,55830 \\
perputaran persediaan & 25 & 1,40 & 7,06 & 4,1556 & 1,66638 \\
perputaran modal kerja & 25 & 1,51 & 181,33 & 28,5712 & 39,20075 \\
Profitabilitas & 25 & $-11,33$ & 9,00 & 1,7808 & 3,79594 \\
\hline Sumber: Data diolah, 2018 & & & & &
\end{tabular}

Statistik deskriptif pada Tabel 1 menunjukkan bahwa nilai minimum dan maksimum variabel perputaran kas $\left(\mathrm{X}_{1}\right)$ sebesar 5,82 dan 5,82. Rata-ratanya (mean) sebesar 15,8956 dengan standar deviasi sebesar 7,37067, hal ini berarti 
bahwa terjadi perbedaan nilai perputaran kas yang diteliti terhadap nilai rataratannya sebesar 7,37067. Nilai minimum dan maksimum variabel perputaran piutang $\left(\mathrm{X}_{2}\right)$ sebesar 2,10 dan 26,21. Rata-ratanya (mean) sebesar 7,7084 dengan standar deviasi sebesar 5,55830, hal ini berarti bahwa terjadi perbedaan nilai perputaran piutang yang diteliti terhadap nilai rata-ratannya sebesar 5,55830.

Nilai minimum dan maksimum variabel perputaran persediaan $\left(\mathrm{X}_{3}\right)$ sebesar 1,40 dan 7,06. Rata-ratanya (mean) sebesar 4,1556 dengan standar deviasi sebesar 1,66638, hal ini berarti bahwa terjadi perbedaan nilai perputaran persediaan yang diteliti terhadap nilai rata-ratannya sebesar 1,66638. Nilai minimum dan maksimum variabel perputaran modal $\left(\mathrm{X}_{4}\right)$ sebesar 1,51 dan 181,33 . Rata-ratanya (mean) sebesar 28,5712 dengan standar deviasi sebesar 39,20075, hal ini berarti bahwa terjadi perbedaan nilai perputaran modal yang diteliti terhadap nilai rataratannya sebesar 39,20075. Nilai minimum dan maksimum variabel profitabilitas (Y) sebesar -11,33 dan 9,00. Rata-ratanya (mean) sebesar 1,7808 dengan standar deviasi sebesar 3,79594, hal ini berarti bahwa terjadi perbedaan nilai profitabilitas yang diteliti terhadap nilai rata-ratannya sebesar 3,79594.

Sebelum dilakukan uji analisis regresi linear berganda maka harus dilakukan uji asumsi klasik. Pengujian ini dilakukan dengan tujuan untuk memastikan hasil yang diperoleh memenuhi asumsi dasar di dalam analisis regresi. Hasil uji asumsi klasik yang dilakukan dalam penelitian ini adalah uji normalitas, uji multikoliniearitas, dan uji heteroskedastisitas. Uji ini bertujuan untuk mengetahui apakah residual dari model regresi yang dibuat berdistribusi normal atau tidak. Untuk menguji apakah data yang digunakan normal atau tidak dapat dilakukan 
I Gusti Ayu Agung Mirah Sanjiwani dan Ketut Alit Suardana. Faktor ...

dengan menggunakan uji Kolmogorov Sminarnov. Apabila koefisien Asymp. Sig. (2-tailed) lebih besar dari 0,05 maka data tersebut dikatakan berdistribusi normal. Hasil pengujian normalitas dapat dilihat pada Tabel 2 sebagai berikut.

Tabel 2.

Hasil Uji Normalitas

\begin{tabular}{cc}
\hline & Unstandardized Residual \\
\hline N & 25 \\
Kolmogorov-Smirnov $Z$ & 0,156 \\
Asymp.Sig.(2-tailed) & 0,119 \\
\hline
\end{tabular}

Sumber: Data diolah, 2018

Berdasarkan Tabel 2 dapat dilihat bahwa nilai Kolmogorov Sminarnov (KS) sebesar 0,156, sedangkan nilai Asymp. Sig. (2-tailed) sebesar 0,119. Hasil tersebut mengindikasikan bahwa model persamaan regresi tersebut berdistribusi normal karena nilai Asymp. Sig. (2-tailed) 0,119 lebih besar dari nilai alpha 0,05.

Uji Multikolinearitas bertujuan untuk menguji apakah di dalam model regresi ditemukan adanya korelasi antar variabel bebas. Model regresi yang baik seharusnya tidak terjadi korelasi diantara variabel bebas. Suatu model regresi dapat dikatakan baik jika tidak terjadi multikolinearitas di dalamnya. Adanya multikolinearitas dapat dilihat dari nilai tolerance atau variance inflation factor (VIF). Jika nilai tolerance lebih dari 10 persen atau VIF Kurang dari 10, maka dikatakan tidak ada multikolinearitas. Uji Multikolinieritas dapat dilihat pada Tabel 3. 
ISSN: 2302-8556

E-Jurnal Akuntansi Universitas Udayana

Vol.26.3.Maret (2019): 2424 -2452

Tabel 3.

Hasil Uji Multikoleniaritas

\begin{tabular}{lcc}
\hline \multicolumn{1}{c}{ Variabel } & Tolerance & VIF \\
\hline Perputaran kas $\left(\mathrm{X}_{1}\right)$ & 0,853 & 1,172 \\
Perputaran piutang $\left(\mathrm{X}_{2}\right)$ & 0,893 & 1,120 \\
Perputaran persediaan $\left(\mathrm{X}_{3}\right)$ & 0,892 & 1,121 \\
Perputaran modal kerja $\left(\mathrm{X}_{4}\right)$ & 0,861 & 1,161 \\
\hline Sumber: Data diolah, 2018 & &
\end{tabular}

Berdasarkan Tabel 3 dapat dilihat bahwa nilai tolerance dan VIF dari variabel perputaran kas, perputaran piutang, perputaran persediaan, perputaran modal kerja dan profitabilitas menunjukkan bahwa nilai tolerance untuk setiap variabel lebih besar dari 10 persen dan nilai VIF lebih kecil dari 10 yang berarti model persamaan regresi bebas dari multikolinearitas.

Uji heteroskedastisitas dilakukan untuk mengetahui apakah dalam model regresi terjadi ketidaksamaan varian. Uji ini dapat dianalisis melalui uji gletser dengan melihat tingkat signifikansi, jika tingkat signifikansi berada di atas 0,05 maka model regresi ini bebas dari masalah heterokedastisitas. Hasil uji heteroskedastisitas dapat ditujukkan di Tabel 4.

Tabel 4.

Hasil Uji Heteroskedastisitas

\begin{tabular}{lcc}
\hline \multicolumn{1}{c}{ Variabel } & Sig. & Keterangan \\
\hline Perputaran kas $\left(\mathrm{X}_{1}\right)$ & 0,282 & Bebas heteroskedastisitas \\
Perputaran piutang $\left(\mathrm{X}_{2}\right)$ & 0,824 & Bebas heteroskedastisitas \\
Perputaran persediaan $\left(\mathrm{X}_{3}\right)$ & 0,600 & Bebas heteroskedastisitas \\
Perputaran modal kerja $\left(\mathrm{X}_{4}\right)$ & 0,108 & Bebas heteroskedastisitas \\
\hline Sumber: Data diolah, 2018 & &
\end{tabular}

Pada Tabel 4 dapat dilihat bahwa nilai sig. dari variabel perputaran kas, perputaran piutang, perputaran persediaan, perputaran modal kerja dan profitabilitas masing-masing sebesar 00,$282 ; 0,824 ; 0,600$; dan 0,108 . Nilai tersebut lebih besar dari 0,05 yang berarti tidak terdapat pengaruh antara variabel bebas 
I Gusti Ayu Agung Mirah Sanjiwani dan Ketut Alit Suardana. Faktor ...

terhadap absolute residual. Dengan demikian, model yang dibuat tidak mengandung gejala heteroskedastisitas.

Analisis selanjutnya adalah analisis regresi linear berganda yang digunakan untuk mengetahui ketergantungan satu variabel terikat hanya pada satu variabel bebas dengan atau tanpa variabel moderator, serta untuk mengetahui ketergantungan satu variabel terikat pada variabel-variabel bebas. Uji ini dilakukan untuk mengetahui besarnya pengaruh perputaran kas $\left(\mathrm{X}_{1}\right)$, perputaran piutang $\left(\mathrm{X}_{2}\right)$, perputaran persediaan $\left(\mathrm{X}_{3}\right)$, dan perputaran modal kerja $\left(\mathrm{X}_{4}\right)$ terhadap profitabilitas (Y). Hasil uji regresi linear berganda dapat dilihat pada Tabel 5.

Tabel 5.

Hasil Analisis Regresi Linear Berganda

\begin{tabular}{|c|c|c|c|c|c|}
\hline \multirow[t]{2}{*}{ Model } & \multicolumn{2}{|c|}{ Unstandardized Coefficients } & \multirow{2}{*}{$\begin{array}{c}\text { Standardized } \\
\text { Coefficients } \\
\text { Beta } \\
\end{array}$} & \multirow[t]{2}{*}{$\mathrm{t}$} & \multirow{2}{*}{ Sig. } \\
\hline & $\mathrm{B}$ & Std. Error & & & \\
\hline (Constant) & 13,724 & 5,492 & & 2,499 & 0,021 \\
\hline perputaran kas & 12,756 & 3,806 & 0,640 & 3,351 & 0,003 \\
\hline perpuataran piutang & 1,222 & 0,540 & 0,016 & 2,263 & 0,045 \\
\hline perputaran persediaan & 3,298 & 0,863 & 0,159 & 3,822 & 0,004 \\
\hline perputaran modal kerja & 1,256 & 0,512 & 0,182 & 2,453 & 0,040 \\
\hline Adjusted $R$ Square & 0,553 & & & & \\
\hline F Statistik & 3,028 & & & & \\
\hline Signifikansi & 0,002 & & & & \\
\hline
\end{tabular}

Berdasarkan hasil analisis regresi linier berganda seperti yang disajikan pada Tabel 5, maka persamaan regresinya adalah sebagai berikut:

$$
Y=13,724+12,756 X_{1}+1,222 X_{2}+3,298 X_{3}+1,256 X_{4}+e
$$

Nilai konstanta sebesar 13,724; berarti apabila perputaran kas $\left(\mathrm{X}_{1}\right)$, perputaran piutang $\left(\mathrm{X}_{2}\right)$, perputaran persediaan $\left(\mathrm{X}_{3}\right)$, dan perputaran modal kerja 
$\left(\mathrm{X}_{4}\right)$ bernilai 0 , maka profitabilitas meningkat sebesar 13,724 persen. Nilai koefisien regresi perputaran kas $\left(\mathrm{X}_{1}\right)$ sebesar 12,756 , berarti jika perputaran kas meningkat 1 kali maka profitabilitas akan meningkat 12,756 persen, dengan asumsi variabel perputaran piutang, perputaran persediaan, dan perputaran modal kerja konstan. Hasil ini menigindikasikan bahwa perputaran kas berbanding lurus dengan profitabilitas. Nilai koefisien regresi perputaran piutang $\left(\mathrm{X}_{2}\right)$ sebesar 1,222 , berarti jika perputaran piutang meningkat 1 kali maka profitabilitas akan meningkat 1,222 persen, dengan asumsi variabel perputaran kas, perputaran persediaan, dan perputaran modal kerja konstan. Hasil ini menigindikasikan bahwa perputaran piutang berbanding lurus dengan profitabilitas.

Nilai koefisien regresi perputaran persediaan $\left(\mathrm{X}_{3}\right)$ sebesar 3,298, berarti jika perputaran persediaan meningkat 1 kali maka profitabilitas akan meningkat 3,298 persen, dengan asumsi variabel perputaran kas, perputaran piutang, dan perputaran modal kerja konstan. Hasil ini menigindikasikan bahwa perputaran persediaan berbanding lurus dengan profitabilitas. Nilai koefisien regresi perputaran modal kerja $\left(\mathrm{X}_{4}\right)$ sebesar 1,256 , berarti jika perputaran modal kerja meningkat 1 kali maka profitabilitas akan meningkat 1,256 persen, dengan asumsi variabel perputaran kas, perputaran piutang, dan perputaran persediaan konstan. Hasil ini menigindikasikan bahwa perputaran modal kerja berbanding lurus dengan profitabilitas.

Sebelum dilakukan pengujian hipotesis, satu hal yang perlu diperhatikan adalah kelayakan model penelitian yang dilakukan dengan uji $\mathrm{F}$ untuk mengetahui pengaruh variabel-variabel independen pada variabel dependen. Sig. Tabel 
ANOVA menunjukkan besarnya angka probabilitas atau signifikansi pada perhitungan ANOVA. Nilai yang tertera digunakan untuk uji kelayanan model analisis (dimana sejumlah variabel x mempengaruhi variabel y) dengan ketentuan angka probabilitas yang baik untuk digunakan sebagai model regresi harus $<0,05$. Nilai ini bisa dilihat pada kolom Sig. Jika Sig. $<0,05$, maka model analisis dianggap layak. Jika Sig. > 0,05, maka model analisis dianggap tidak layak. Hasil analsiis uji kelayakan ditunjukkan pada Tabel 6.

Tabel 6.

Hasil Uji Kelayakan Model (Uji F)

\begin{tabular}{llrrrrr}
\hline & Model & Sum of Squares & Df & Mean Square & F & \multicolumn{1}{l}{ Sig. } \\
\hline 1 & Regression & 130,428 & 4 & 32,607 & 3,028 & 0,002 \\
& Residual & 215,392 & 20 & 10,770 & & \\
Total & 345,820 & 24 & & & \\
\hline
\end{tabular}

Sumber : Data diolah, 2018

Hasil Uji Anova atau (F test) pada Tabel 6 menunjukan nilai $\mathrm{F}$ hitung sebesar 3,028 dengan signifikansi 0,002 yang probabilitas signifikan lebih kecil dari alpha 0,05 . Ini menunjukan model yang digunakan pada penelitian ini adalah layak. Perputaran kas, perputaran piutang, perputaran persediaan, dan perputaran modal kerja dapat digunakan untuk memprediksi profitabilitas atau dapat dikatakan bahwa perputaran kas, perputaran piutang, perputaran persediaan, dan perputaran modal kerja secara bersama-sama berpengaruh terhadap profitabilitas.

Analisis koefisien determinasi dilakukan untuk mengukur seberapa besar variabel bebas mampu menjelaskan perubahan variabel terikatnya. Pada penelitian ini koefisien determinasi dilihat melalui nilai Adjust $R$ Square yang terlihat pada Tabel 7 sebagai berikut. 
Tabel 7.

Hasil Uji Koefisien Determinasi $\left(\mathbf{R}^{2}\right)$

\begin{tabular}{ccrrr}
\hline Model & $\mathrm{R}$ & R Square & Adjusted $R$ Square & $\begin{array}{c}\text { Std. Error of the } \\
\text { Estimate }\end{array}$ \\
\hline 1 & 0,614 & 0,577 & 0,553 & 3,28171 \\
\hline Sumber:Data diolah, 2018 & & &
\end{tabular}

Berdasarkan Tabel 7 Adjusted $R$ Square sebesar 0,553 mempunyai arti bahwa sebesar 55,3 persen variasi profitabilitas dipengaruhi oleh variasi perputaran kas, perputaran piutang, perputaran persediaan, dan perputaran modal kerja, sedangkan sisanya sebesar 44,7 persen djelaskan oleh faktor lain yang tidak dimasukkan ke dalam model.

Uji statistik t pada dasarnya dilakukan untuk menunjukkan seberapa jauh pengaruh satu variabel independen secara individual dalam menerangkan variabel variabel dependen. Uji statistik dilakukan dengan membandingkan hasil nilai signifikasi dengan $\alpha=0,05$ dan dapat dijelaskan pada Tabel 8 sebagai berikut.

Tabel 8.

Hasil Analisis Uji Statistik t

\begin{tabular}{lcccc}
\hline Variabel & $\begin{array}{c}\text { Koefisien } \\
\text { Regresi }\end{array}$ & t hitung & Sig & Hasil Hipotesis \\
\hline X1 & 12,756 & 3,351 & 0,003 & H1 diterima \\
X2 & 1,222 & 2,263 & 0,045 & H2 diterima \\
X3 & 3,298 & 3,822 & 0,004 & H3 diterima \\
X4 & 1,256 & 2,453 & 0,040 & H3 diterima \\
\hline
\end{tabular}

Sumber: Data diolah, 2018

Berdasarkan dari hasil pengujian yang ditunjukan Tabel 8 diketahui bahwa tingkat signifikan $\mathrm{t}$ sebesar 0,003 yang berarti lebih kecil atau dibawah nilai $\alpha=$ 0,05. Hal ini menunjukan bahwa perputaran kas berpengaruh positif dan signifikan terhadap profitabilitas. Hal ini berarti adanya pengaruh antara 
perputaran kas dengan profitabilitas, dimana ketika perputaran kas meningkat maka profitabilitas juga akan meningkat.

Perputaran kas merupakan perbandingan antara penjualan dengan jumlah kas rata-rata. Perputaran kas menunjukkan kemampuan kas dalam menghasilkan pendapatan sehingga dapat dilihat berapa kali uang kas berputar dalam satu periode tertentu. Semakin tinggi perputaran kas ini akan semakin baik. Karena ini berarti semakin tinggi efisiensi penggunaan kasnya dan keuntungan yang diperoleh akan semakin besar pula (Kasmir, 2016). Perputaran kas berfungsi untuk mengukur tingkat kecukupan modal kerja perusahaan yang dibutuhkan untuk membayar tagihan dan membiayai penjualan. Artinya untuk mengukur tingkat ketersediaan kas untuk membayar tagihan (utang) dan biaya-biaya yang berkaitan dengan penjualan. Hasil penelitian ini sesuai dengan penelitian Nuriyani (2017) dan Putri (2016) yang menyatakan perputaran kas berpengaruh terhadap profitabiltas. Studi empiris lain dari Haryanto et al. (2018) juga menyebutkan bahwa perputaran kas berpengaruh terhadap profitabiltas. Penelitian lain dari Kasozi (2017) juga menyatakan bahwa perputaran kas berpengaruh positif terhadap profitabiliats. Artinya naik turunnya persdiaan kas akan mempengaruhi profitabilitas usaha.

Berdasarkan dari hasil pengujian yang ditunjukan Tabel 8 diketahui bahwa tingkat signifikan t sebesar 0,045 yang berarti lebih kecil atau dibawah nilai $\alpha=$ 0,05. Hal ini menunjukan bahwa perputaran piutang berpengaruh positif dan signifikan terhadap profitabilitas. Hal ini berarti adanya pengaruh antara 
perputaran piutang dengan profitabilitas, dimana ketika perputaran piutang meningkat maka profitabilitas juga akan meningkat.

Piutang merupakan salah satu bentuk investasi yang menyerap sebagian dari modal perusahaan. Bila perusahaan menggunakan modal sendiri seluruhnya, maka dengan piutang modal yang tersedia untuk investasi bentuk lain (persediaan, aktiva tetap dan lain-lain) akan berkurang. Dengan demikian, biaya modal besarnya sama dengan besarnya biaya modal sendiri. Bilamana modal sendiri tidak mencukupi sehingga perusahaan terpaksa menggunakan pinjaman bank, maka timbul biaya yang eksplisit dalam bentuk bunga modal pinjaman.

Peningkatan piutang yang diiringi oleh meningkatnya piutang tak tertagih perlu mendapat perhatian. Untuk itu sebelum suatu perusahaan memutuskan melakukan penjualan kredit, maka terlebih dahulu diperhitungkan mengenai jumlah dana yang diinvestasikan dalam piutang, syarat penjualan dan pembayaran yang diinginkan, kemungkinan kerugian piutang (piutang tak tertagih) dan biayabiaya yang akan timbul dalam menangani piutang bisa diatasi. Hasil penelirian ini didukung oleh penelitian Tiong (2018) dan Damanik (2011) serta penelitian Inastia (2018) bahwa perputaran piutang berpengaruh signifikan terhadap profitabilitas (ROA). Hasil studi empiris Lydia (2018) dan Jindal et al. (2017) yang menemukan bahwa perputaran piutang berpengaruh signifikan terhadap profitabilitas (ROA).

Berdasarkan dari hasil pengujian yang ditunjukan Tabel 8 diketahui bahwa tingkat signifikan $\mathrm{t}$ sebesar 0,004 yang berarti lebih kecil atau dibawah nilai $\alpha=$ 0,05. Hal ini menunjukan bahwa perputaran persediaan berpengaruh positif dan 
signifikan terhadap profitabilitas. Hal ini berarti adanya pengaruh antara perputaran persediaan dengan profitabilitas, dimana ketika perputaran persediaa meningkat maka profitabilitas juga akan meningkat.

Setiap perusahaan, apakah perusahaan itu perusahaan perdagangan ataupun perusahaan pabrik serta perusahaan jasa selalu mengadakan persediaan. Tanpa adanya persediaan, para pengusaha akan dihadapkan pada resiko bahwa perusahaannya pada suatu waktu tidak dapat memenuhi keinginan pelanggan yang memerlukan atau meminta barang/jasa. Persediaan diadakan apabila keuntungan yang diharapkan dari persediaan tersebut hendaknya lebih besar daripada biayabiaya yang ditimbulkannya.

Periode perputaran persediaan ini perlu diperhatikan untuk mengetahui berapa lama waktu yang dibutuhkan oleh perusahaan untuk menghabiskan persediaan dalam proses produksinya. Hal ini dikarenakan semakin lama periode perputaran persediaan, maka semakin banyak biaya yang harus dikeluarkan oleh perusahaan untuk menjaga agar persediaan di gudang tetap baik. Oleh karena itu diperlukan penghematan ongkos penyimpanan dan pemeliharaan agar keuntungan yang diperoleh semakin besar sehingga semakin kecil biaya yang harus ditanggung perusahaan, semakin besar profitabilitas yang akan didapat dan perputaran persediaan semakin tinggi. Hasil penelitian ini didukung oleh hasil penelitian dari Setiyanto (2018) dan Ariati (2011) serta Mwaura (2017) menyatakan bahwa perputaran persediaan memberikan pengaruh signifikan terhadap profitabilitas. 
Berdasarkan dari hasil pengujian yang ditunjukan Tabel 8 diketahui bahwa tingkat signifikan t sebesar 0,040 yang berarti lebih kecil atau dibawah nilai $\alpha=$ 0,05. Hal ini menunjukan bahwa perputaran modal kerja berpengaruh positif dan signifikan terhadap profitabilitas. Hal ini berarti adanya pengaruh antara perputaran modal dengan profitabilitas, dimana ketika perputaran modal meningkat maka profitabilitas juga akan meningkat.

Munawir (2015) menyatakan bahwa rasio perputaran modal kerja menunjukkan hubungan antara modal kerja dengan penjualan. Faktor modal kerja mempengaruhi tinggi rendahnya profitabilitas. Setiap perusahaan dalam operasionalnya membutuhkan modal karena modal berpengaruh terhadap perusahaan untuk mencapai tujuannya, sehingga profitabilitas tinggi sangat mendukung operasional perusahaan secara maksimal (Indradewi dan Widyarti, 2016). Hasil penelitian ini di dukung oleh penelitain Tran et al. (2017) yang mengemukakan bahwa efisiensi manajemen modal kerja berpengaruh signifikan terhadap profitabilitas. Hasil penelitian ini juga diperkuat oleh Sariyana (2016), Kusumo (2018), Ukaegbu (2014) dan Felany (2018) menunjukkan bahwa perputaran modal kerja (working capital turnover) berpengaruh positif terhadap profitabilitas.

\section{SIMPULAN}

Berdasarkan hasil analisis maka dapat ditarik kesimpulan yaitu perputaran kas berpngaruh signifikan terhadap profitabilitas. Hal ini menunjukkan bahwa meningkatnya perputaran kas perusahaan otomotif, maka cenderung akan 
meningkatkan profitabilitas. Perputaran piutang berpngaruh signifikan terhadap profitabilitas. Hal ini menunjukkan bahwa meningkatnya perputaran piutang perusahaan otomotif, maka cenderung akan meningkatkan profitabilitas. Perputaran persediaan berpngaruh signifikan terhadap profitabilitas. Hal ini menunjukkan bahwa meningkatnya perputaran persediaan perusahaan otomotif, maka cenderung akan meningkatkan profitabilitas. Perputaran modal kerja berpngaruh signifikan terhadap profitabilitas. Hal ini menunjukkan bahwa meningkatnya perputaran modal kerja perusahaan otomotif, maka cenderung akan meningkatkan profitabilitas.

Saran yang dapat diberikan dari hasil penelitian adalah bagi manajemen perusahaan sebaiknya memperhatikan perputaran kas, pperputaran piutang, perputaran piutang, perputaran persediaan dan perputaran modal kerja karena memiliki pengaruh yang signifikan terhadap profitabilitas. Dalam penelitian ini yang diteliti hanya terbatas pada pengaruh perputaran kas, perputaran piutang, perputaran piutang, perputaran persediaan dan perputaran modal kerja dan profitabilitas. Sedangkan faktor-faktor lain yang juga berpengaruh terhadap profitabilitas yang belum diungkap berapa besar pengaruhnya, sehingga pada penelitian selanjutnya dapat dibahas faktor-faktor lain yang belum diteliti dalam penelitian ini.

\section{REFERENSI}

Adawia, Popon Rabia., dan Sri Khotijah. (2017). Analisis Pengaruh Perputaran Persediaan Terhadap Profitabilitas Perusahaan Pada PT. Indocement Tunggal Prakasa, Tbk.. Jurnal JEB, 1(2), 37-56. 
Ainiyah, Qurotul. (2016). Pengaruh Perputaran Piutang, Perputaran Persediaan Dan Debt To Equity Ratio Terhadap Profitabilitas. Jurnal Ilmu Dan Riset Manajemen, 5(1).

Beale, Hugh., Gullifer, Louise., and Paterson, Sarah (2016). A case for interfering with freedom of contract? An empirically-informed study of bans of assignment. Journal of Business Law, 3, 203-230.

Botutihe, Nur Atni. (2017). Analisis Rasio Profitabilitas Laporan Laba Rugi Pada Home Industri Cita Rasa Pagimana Kabupaten Banggai. Jurnal EMOR, 2(2), 33-46.

Dodokerang, Lucia Mevy., Parengkuan Tommy., dan Marjam Mangantar. (2018). Analisis Perputaran Modal Kerja Terhadap Profitabilitas Pada Perusahaan Farmasi Terdaftar Di Bursa Efek Indonesia (BEI) Tahun 2012-2016. Jurnal EMBA, 6(3), $1818-1827$.

Erik Pebrin, Naibaho dan Sri Rahayu (2014). Pengaruh Perputaran Piutang Dan Perputaran Persediaan Terhadap Profitabilitas (Studi Empiris Perusahaan Makanan Dan Minuman Yang Terdaftar Di Bei Tahun 2008- 2012). Jurnal E-Proceeding of Management, 1(3), 279-294.

Evci, Samet., and Nazan Şa. (2018). The Effect of Working Capital Management on Profitability in Emerging Countries: Evidence from Turkey. Financial Management from an Emerging Market Perspective, 205-218.

Fatimah, Syukriah, \& Nurul, A. (2017). Pengendalian Persediaan Bahan Baku untuk Waste Water Treatment Plant (WWTP) dengan. Prosiding SNTI dan SATELIT 2017 (h: 137-142). Malang: Jurusan Teknik Industri Universitas Brawijaya.

Ghozali, Imam. 2016. Aplikasi Analisis Multivariate dengan Program IBM SPSS. 23. Semarang: BPFE Universitas Diponegoro.

Harahap, Sofyan Syafri. 2015. Analisis Kritis atas Laporan Keuangan. Edisi 1-10. Jakarta: Rajawali Pers.

Haryanto., Akhmad Sodikin., dan Ella Siti Chaeriah. (2018). Effect of Turnover of Cash, Receivables Turnover and Inventory Turnover on Return on Assets (ROA): Case Study in PT Indofood Sukses Makmur TBK. International Journal of Arts Humanities and Social Sciences, 3(1), 62-81. 
I Gusti Ayu Agung Mirah Sanjiwani dan Ketut Alit Suardana. Faktor ...

Inastia, Nabila., dan Aditya Wardhana. (2018). The Influence Of Receivable Turnover And Inventory Turnover On Profitability At PT. X (Period Of Year 2016-2017). e-Proceeding of Management, 5(1), 1138-1144.

Indradewi, C., \& Widyarti, E. T. (2016). Analisis Pengaruh Manajemen Modal Kerja Terhadap Profitabilitas Perusahaan Manufaktur Sektor Industri Dasar dan Kimia Go Public Pada BEI. Diponegoro Journal of Management, 5(2), $1-11$.

Jindal, Sakshi. (2016). Factors Affecting Demand for Money: An Empirical Study Based on Time Series Analysis. International Research Journal of Engineering and Technology, 3(6), 991-994.

Jindal, Divya., Simran Jain., dan Vartika. (2017). Effect of Receivables Management on Profitability: A Study of Commercial Vehicle Industry in India. International Journal of Applied Sciences and Management, 2(2), 246-255.

Kasmir. 2016. Analisis Laporan Keuangan. Jakarta: Raja Grafindo Persada.

Kasozi, Jason. (2017) The effect of working capital management on profitability: a case of listed manufacturing firms in South Africa. Investment Management and Financial Innovations, 14(2), 336-346.

Kusumo, Candra Yuwono., dan Ari Darmawan. (2018). Pengaruh Perputaran Modal Kerja, Ukuran Perusahaan, Dan Diversifikasi Terhadap Profitabilitas. Jurnal Administrasi Bisnis, 5(1), 83-89.

Katili, Indra Ningsih., Jenny Morasa., dan Novi S. Budiarso. (2017). Evaluasi Penerapan Sistem Akuntansi Penerimaan Dan Pengeluaran Kas Pada PT. Ciputra Internasional Cabang Manado. Jurnal Riset Akuntansi Going Concern, 12(1), 180-186.

Lestari, Nurri. (2017). Pengaruh Perputaran Kas, Perputaran Piutang Usaha Dan Perputaran Persediaan Terhadap Profitabilitas Pada Perusahaan Sub Sektor Makanan Dan Minuman Yang Terdaftar Di Bursa Efek Indonesia Tahun 2011 - 2015. Jurnal Ekonomi, 1-13.

Lubis, Abdul Rahman. (2016). Analisis Sumber Dan Penggunaan Modal Kerja Dalam Meningkatkan Likuiditas Perusahaan (Studi Kasus Pada Pt. Siantar Top Tbk.). Jurnal Ilmiah. Fakultas Ekonomi Dan Bisnis Islam Universitas Islam Negeri Sumatera Utara Medan. 
Machmud, Sella., Sri Murni Rustandi., dan Maryam Mangantar. (2015). Analisis Perbandingan Perputaran Modal Kerja Pada Perusahaan Industri Food And Beverage Yang Terdaftar Di BEI Tahun 2011-2013. Jurnal EMBA, 3(1), 1303-1312.

Masri, Dasrizal. (2014). Analisis Perputaran Modal Kerja Pada Usaha Ekonomi Desa Ued-Sp Tuah Negeri Rambah Hilir Rokan Hulu. Jurnal Ilmiah. Jurusan Akuntansi, Fakultas Ekonomi, Universitas Pasir Pengaraian.

Mulyadi. 2016. Sistem Akuntansi. Jakarta: Salemba Empat.

Munawir, S. 2015. Analisis Laporan Keuangan. Jakarta: Salemba Empat.

Ndebugri, Haruna., and Emmanuel Tweneboah Senzu. (2017). Account receivable management across Industrial sectors in Ghana; analyzing the economic effectiveness and efficiency. Munich Personal RePEc Archive, 1-43.

Nuriyani dan Rachma Zannati. (2017). Pengaruh Perputaran Kas Dan Perputaran Piutang Terhadap Profitabilitas Perusahaan Sub-Sektor Food and Beverages Tahun 2012-2016. Jurnal Riset Manajemen Dan Bisnis Fakultas Ekonomi Uniat, 2(3), $422-432$.

Pangalila, Novita Ingrid. (2017). Pengaruh Perputaran Kas Dan Perputaran Piutang Terhadap Profitabilitas Pada Perusahaan Manufaktur Yang Terdaftar Di Bursa Efek Indonesia Periode 2012-2016. Tugas Akhir. Program Studi Akuntansi Akademi Akuntansi Permata Harapan Batam.

Polycarp, W. and Tabitha, N. (2016). Effect of Working Capital Management on the Financial Performance of Listed Manufacturing Firms in Kenya. Asian Journal of Business and Management, 4, 195-208.

Putri, L Rizkiyanti, dan Lucy Sri Musmini. (2013). Pengaruh Perputaran Kas Terhada Profitabilitas Pada PT. Tirta Mumbul Jaya Abadi Singaraja Periode 2008-2012. Jurnal Akuntansi Profesi, 3(2).

Rahayu, E. A dan J. Susilowibowo. (2014). Pengaruh Perputaran Kas, Perputaran Piutang Dan Perputaran Persediaan Terhadap Profitabilitas Perusahaan Manufaktur. Jurnal Ilmu Manajemen, 2(4), 1444-1455.

Rahayu, Sri., Mahsina., dan Susi Tri Wahyuni. (2017). Analisis Pengaruh Perputaran Persediaan Dan Perputaran Piutang Terhadap Modal Kerja Pada Pt Unilever Indonesia, Tbk. Jurnal Ekonomi Akuntansi, 3(3), 593-603.

Ramesh, G., Hamad Al-Habsi., and Tammam Al-Sharji. (2017). Effect Of Working Capital Management On The Financial Performance Of 
I Gusti Ayu Agung Mirah Sanjiwani dan Ketut Alit Suardana. Faktor ...

Manufacturing Firms In Sultanate Of Oman. Innovative Journal Of Business And Management, 6(3), 38-42.

Rangkuti, Freddy. 2015. Riset Pemasaran. Cetakan keduabelas. Jakarta: Gramedia.

Rasyid, Abdul. (2015). Effects Of Ownership Structure, Capital Structure, Profitability And Company's Growth Towards Firm Value. International Journal of Business and Management Invention, 4(4), 25-31.

Saifudin, dan Firda Pri Ardani. (2017). Sistem Informasi Akuntansi Penerimaan Dan Pengeluaran Kas Dalam Meningkatkan Pengendalian Internal Atas Pendapatan Pada Rsup Dr. Kariadi Semarang. Jurnal Riset Akutansi Keuangan. 2(2), 123-138.

Saputra, Samsul Hadi Agus. (2017). Pengaruh Perputaran Modal Kerja Terhadap Profitabilitas Pada Perusahaan Otomotif Yang Terdaftar Di Bursa Efek Indonesia. E-Journal Administrasi Bisnis, 5(4), 1215-1228.

Sugiyono. 2017. Metodologi Penelitian Kuantitatif, Kualitatif, dan R\&D. Bandung: CV Alfabeta.

Sariyana, Bagus Mangdahita., Fridayana Yudiaatmaja., dan I Wayan Suwendra. (2016). Pengaruh Perputaran Modal Kerja Dan Likuiditas Terhadap Profitabilitas (Studi Pada Perusahaan Food And Beverages). e-Journal Bisma Universitas Pendidikan Ganesha Jurusan Manajemen, 4, 1-10.

Surya, Sarjito., Ruly Ruliana., dan Dedi Rossidi Soetama. (2017). Pengaruh Perputaran Kas dan Perputaran Persediaan Terhadap Profitabilitas. Jurnal Ilmu Akuntansi, 10(2), 313-332.

Setiyantoa, Adi Irawan., dan Septian Bayu Ajib. (2018). Pengaruh Inventory Conversion Period, Average Collection Period, Payables Deferral Period dan Cash Conversion Cycle terhadap Profitabilitas Perusahaan. Journal of Applied Accounting and Taxation. 3(1), 17-25.

Tiong, Piter. (2017). Pengaruh Perputaran Piutang Terhadap Profitabilitas Pada Perusahaan PT Mitra Phinastika Mustika Tbk. Journal Of Management \& Business, 1-25.

Ukaegbu, B. (2014). The significance of working capital management in determining firm profitability: Evidence from developing economies in Africa. Research in International Business, 31, 1-16. 
Tran, H., Abbott, M., \& Yap, C. J. (2017). How does working capital management affect the profitability of Vietnamese small- and medium-sized enterprises? Journal of Small Business and Enterprise Development, 24, 1314.

Verawati, V.L. dan Oetomo. (2014). Pengaruh perputaran modal kerja, perputaran piutang, dan perputaran persediaan terhadap profitabilitas perusahaan Tekstil. Jurnal Manajemen. STIESIA Surabaya.

http://www.idx.co.id 